\title{
Кинетические закономерности УДК 678-01:620:17 кристаллизации термоэластопластов на основе рандом полипропилена и бутадиен-нитрильного каучука
}

\section{Kinetic regularities of crystallization of thermoelastoplasts based on polypropylene and nitrile butadiene rubber}

\section{А. Д. Гулиев}

Институт Полимерных Материалов

Национальной Академии Наук Азербайджана
A. J. Guliyev

Institute of Polymer Materials

of the Azerbaijan National Academy of Sciences

Поступила в редакцию 07.07.2020, принята к печати 28.07.2020

\section{Абстракт}

В работе приводятся результаты исследования влияния соотношения рандом полипропилена с бутадиен-нитрильным каучуком (CKH-40)на закономерность изменения удельного объёма от температуры. Определены значения занятого и свободного удельного объёмов композиционных материалов. На основании теории Аврами изучены кинетические закономерности кристаллизации термоэластопластов в зависимости от содержания эластомерного компонента в составе рандом полипропилена.

\section{Abstract}

The paper presents the results of a study of the effect of the ratio of random propylene with nitrile butadiene rubber (SKN-40) on the regularity of changes in specific volume from temperature. The values of the occupied and free specific volumes of composite materials are determined. Based on the Avrami theory, the kinetic regularities of crystallization of thermoelastoplasts were studied depending on the content of the elastomeric component in the composition of random polypropylene.

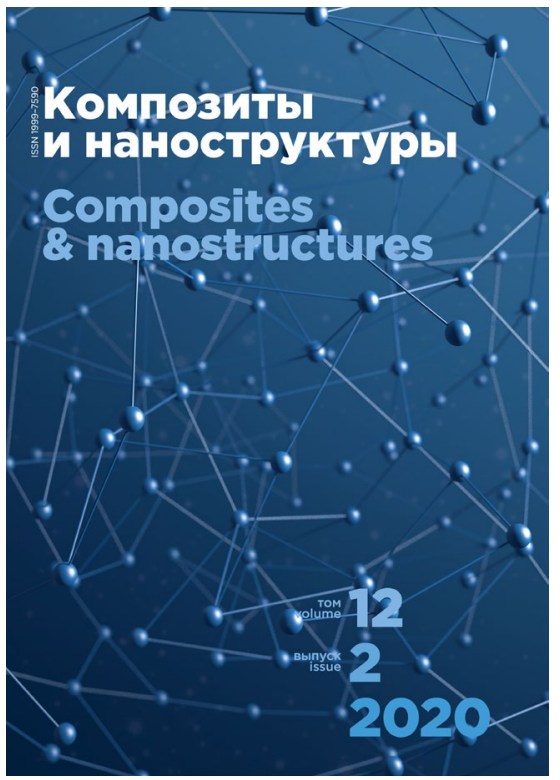

